\title{
Quaternary Stratigraphy and Stratigraphic Nomenclature Revisions in Kansas
}

\author{
Anthony L. Layzell ${ }^{1,2}$, Robert S. Sawin ${ }^{1,2}$, Rolfe D. Mandel ${ }^{1}$, Greg A. Ludvigson ${ }^{1,2}$, \\ Evan K. Franseen ${ }^{1,2}$, Ronald R. West ${ }^{2,3}$, W. Lynn Watney ${ }^{1,2}$ \\ ${ }^{1}$ Kansas Geological Survey, 1930 Constant Avenue, Lawrence, Kansas 66047 \\ ${ }^{2}$ Member, Stratigraphic Nomenclature Committee, Kansas Geological Survey \\ ${ }^{3}$ Emeritus Professor, Kansas State University, Manhattan, Kansas 66506
}

\begin{abstract}
This paper outlines Quaternary nomenclature changes to Zeller (1968) that have been adopted by the Kansas Geological Survey (KGS). The KGS formally recognizes two series/epochs for the Quaternary: the Holocene and Pleistocene. Pleistocene stage/age names Kansan, Aftonian, Nebraskan, and Yarmouthian are abandoned and replaced with the broader term "pre-Illinoian." Formation names Bignell, Peoria, Gilman Canyon, and Loveland are maintained for loess units. Formation names for the following alluvial lithostratigraphic units are abandoned: Crete, Sappa, Grand Island, Fullerton, and Holdrege. The Severance Formation is adopted as a new lithostratigraphic unit for thick packages of late Pleistocene alluvium and colluvium in Kansas. The DeForest Formation is accepted as a valid lithostratigraphic unit for deposits of fine-grained Holocene alluvium in Kansas. Formation names Iowa Point, Nickerson, and Cedar Bluffs for glacial tills and Atchison and David City for glaciofluvial deposits are abandoned. The Afton and Yarmouth Soils are abandoned as pedostratigraphic units, whereas the Sangamon Geosol and Brady Geosol are maintained.
\end{abstract}

\section{Introduction}

The most comprehensive report on Quaternary geology in the state of Kansas is found in the Pleistocene Geology of Kansas (Frye and Leonard, 1952). Bayne and O'Connor (1968) used much of the data in that publication for their classification of Quaternary deposits in Zeller's edited volume The Stratigraphic Succession in Kansas (Zeller, 1968), which represents the currently accepted stratigraphic guide and chart for Kansas. The stratigraphic framework for Quaternary deposits in these publications was based on the classic four-fold model of Pleistocene glaciations (i.e., Wisconsin, Illinoian, Kansan, and Nebraskan Stages) (table 1). This stratigraphic framework, however, was questioned in the 1970s and 1980s (e.g., Boellstorff, 1978a, 1978b), resulting in proposals to abandon the pre-Illinoian stratigraphic nomenclature (e.g., Hallberg, 1986; Richmond and Fullerton, 1986). Since then, further changes to the Quaternary stratigraphic nomenclature in Kansas have been suggested or proposed (e.g., Aber, 1991; Mandel and Bettis, 2001); however, no attempt has been made to formally assess or adopt these proposals. This paper reports on nomenclature changes to Zeller (1968) that are now formally adopted by the Kansas Geological Survey (KGS).

\section{Quaternary System/Period \\ Chronostratigraphic framework}

The formal division of the Quaternary is the responsibility of the International Union of Geological Sciences (IUGS) International Commission on Stratigraphy (ICS) Subcommission on Quaternary Stratigraphy (SQS), in partnership with the International Union for Quaternary Research (INQUA) Commission on Stratigraphy and Chronology.

Zeller (1968) placed all Quaternary deposits into a single series/epoch, the Pleistocene (fig. 1). Following the IUGS ICS SQS (Cohen and Gibbard, 2011), the KGS now recognizes two series/ epochs: the Holocene (Walker et al., 2009) and Pleistocene (Riccardi, 2009) (fig. 1, table 2). The basal age of the Holocene series/ epoch is set at $11.7 \mathrm{ka}$ and essentially replaces the "Recent Stage" of Zeller (1968), which represented the last $10 \mathrm{ka}$. The IUGS ICS SQS subdivides the Pleistocene epoch into three stages/ages: Early, Middle, and Late (Cohen and Gibbard, 2011). At present, these stages/ages are not formalized and are therefore not adopted by the KGS. Due to the lack of formalization, the IUGS ICS subdivides the Pleistocene into four "super-stages" based on formally defined Global Stratotype Section and Points (GSSP): Gelasian, 
Table 1. Previous classification of Quaternary deposits in Kansas (Bayne and O'Connor, 1968).

\begin{tabular}{|c|c|c|c|c|c|c|}
\hline \multirow{2}{*}{$\begin{array}{c}\text { Time- } \\
\text { stratigraphic } \\
\text { units }\end{array}$} & \multicolumn{6}{|c|}{ Rock-stratigraphic units } \\
\hline & \multicolumn{2}{|c|}{ Northeastern area } & \multicolumn{2}{|c|}{ Southeastern area } & \multicolumn{2}{|c|}{ Central and Western area } \\
\hline Recent Stage & \multicolumn{6}{|c|}{ Eolian and fluvial deposits } \\
\hline \multirow{4}{*}{$\begin{array}{l}\text { Wisconsinan } \\
\text { Stage }\end{array}$} & $\begin{array}{l}\text { Bignell } \\
\text { Formation }\end{array}$ & $\begin{array}{l}\text { Fluvial } \\
\text { deposits }\end{array}$ & $\begin{array}{l}\text { Bignell } \\
\text { Formation }\end{array}$ & $\begin{array}{l}\text { Fluvial } \\
\text { deposits }\end{array}$ & $\begin{array}{l}\text { Bignell } \\
\text { Formation }\end{array}$ & $\begin{array}{l}\text { Fluvial } \\
\text { deposits }\end{array}$ \\
\hline & \multicolumn{6}{|c|}{ Brady Soil } \\
\hline & $\begin{array}{c}\text { Peoria } \\
\text { Formation }\end{array}$ & \multirow{2}{*}{$\begin{array}{l}\text { Fluvial } \\
\text { deposits }\end{array}$} & $\begin{array}{c}\text { Peoria } \\
\text { Formation }\end{array}$ & \multirow{2}{*}{$\begin{array}{c}\text { Fluvial } \\
\text { deposits }\end{array}$} & $\begin{array}{c}\text { Peoria } \\
\text { Formation }\end{array}$ & \multirow{2}{*}{$\begin{array}{l}\text { Fluvial } \\
\text { deposits }\end{array}$} \\
\hline & $\begin{array}{c}\text { Gilman } \\
\text { Canyon } \\
\text { Formation }\end{array}$ & & & & & \\
\hline $\begin{array}{l}\text { Sangamonian } \\
\text { Stage }\end{array}$ & \multicolumn{6}{|c|}{ Sangamon Soil } \\
\hline \multirow{2}{*}{$\begin{array}{l}\text { Illinoisan } \\
\text { Stage }\end{array}$} & \multirow{2}{*}{$\begin{array}{l}\text { Loveland } \\
\text { Formation }\end{array}$} & \multirow{2}{*}{$\begin{array}{l}\text { Fluvial } \\
\text { deposits }\end{array}$} & \multirow{2}{*}{$\begin{array}{l}\text { Loveland } \\
\text { Formation }\end{array}$} & \multirow{2}{*}{$\begin{array}{c}\text { Fluvial } \\
\text { deposits }\end{array}$} & \multicolumn{2}{|c|}{ Loveland Formation } \\
\hline & & & & & \multicolumn{2}{|c|}{ Crete Formation } \\
\hline $\begin{array}{l}\text { Yarmouthian } \\
\text { Stage }\end{array}$ & \multicolumn{6}{|c|}{ Yarmouth Soil } \\
\hline \multirow{5}{*}{ Kansan Stage } & Loess & $\begin{array}{c}\text { Fluvial } \\
\text { deposits }\end{array}$ & \multirow{5}{*}{\multicolumn{2}{|c|}{ Fluvial deposits }} & \multirow{2}{*}{\multicolumn{2}{|c|}{ Sappa Formation }} \\
\hline & \multicolumn{2}{|c|}{ Cedar Bluffs Till } & & & & \\
\hline & \multicolumn{2}{|c|}{ Fluvial deposits } & & & \multirow{3}{*}{\multicolumn{2}{|c|}{ Grand Island Formation }} \\
\hline & \multicolumn{2}{|c|}{ Nickerson Till } & & & & \\
\hline & \multicolumn{2}{|c|}{ Atchison Formation } & & & & \\
\hline Aftonian Stage & \multicolumn{6}{|c|}{ Afton Soil } \\
\hline \multirow{3}{*}{$\begin{array}{l}\text { Nebraskan } \\
\text { Stage }\end{array}$} & Loess & $\begin{array}{c}\text { Fluvial } \\
\text { deposits }\end{array}$ & \multirow{3}{*}{\multicolumn{2}{|c|}{ Fluvial deposits }} & \multicolumn{2}{|c|}{ Fullerton Formation } \\
\hline & \multicolumn{2}{|c|}{ Iowa Point Till } & & & \multirow{2}{*}{\multicolumn{2}{|c|}{ Holdrege Formation }} \\
\hline & David C & rmation & & & & \\
\hline
\end{tabular}

Calabrian, Ionian (Middle), and Tarantian (Upper) (fig. 1; Cohen and Gibbard, 2011; Cohen et al., 2013). However, only two (the basal boundaries of the Gelasian and Calabrian) have been ratified. Given that the locations of the Pleistocene "super-stages" in the Kansas stratigraphic succession have not been established and that the IUGS ICS SQS recognizes that the use of "super-stages" is unsatisfactory for use beyond the Mediterranean region type sections (Cohen and Gibbard, 2011), the KGS does not adopt the use of this nomenclature.

The stratigraphic framework for Quaternary deposits in Zeller (1968) was based on the classic model of Pleistocene glaciations that recognized four glacial intervals (Wisconsin, Illinoian, Kansan, and Nebraskan) and three interglacial intervals (Sangamonian, Yarmouthian, and Aftonian) that were represented by buried soils (fig. 1, table 1). Zeller's chart also included the Pearlette volcanic ash bed, which was used by early researchers as a stratigraphic marker and was assumed to represent the end of Kansan time (e.g., Frye and Leonard, 1952; Reed and Dreeszen, 1965). Much of this classic conceptual stratigraphic framework, however, was questioned in the 1970s and 1980s (e.g., Boellstorff, 1978a, 1978b, 1978c; Hallberg, 1986). The rationale for redefinition of Pleistocene stage names was based on 1) complexities identified in the glacial succession, including the presence of multiple tills and paleosols beneath the so-called "Nebraskan" till (see Hallberg, 1986) and 2) the recognition that the Pearlette ash actually consisted of multiple distinct ash beds with significantly different ages (e.g., Naeser et al., 1973; Boellstorff, 1976; Izett, 1981). To date, six distinct Quaternary volcanic ash beds have been identified in Kansas: Lava Creek B (0.6 Ma), Bishop (0.74 Ma), Tsankawi (1.15 Ma), Mesa Falls (1.3 Ma), Guaje (1.47 Ma), and Huckleberry Ridge (2.1 Ma) (Izett and Wilcox, 1982; Ward et al., 1993).

In 1986, a compendium of articles published in Quaternary 
Zeller, 1968

KGS Nomenclature, 2017

ICS Nomenclature, 2017

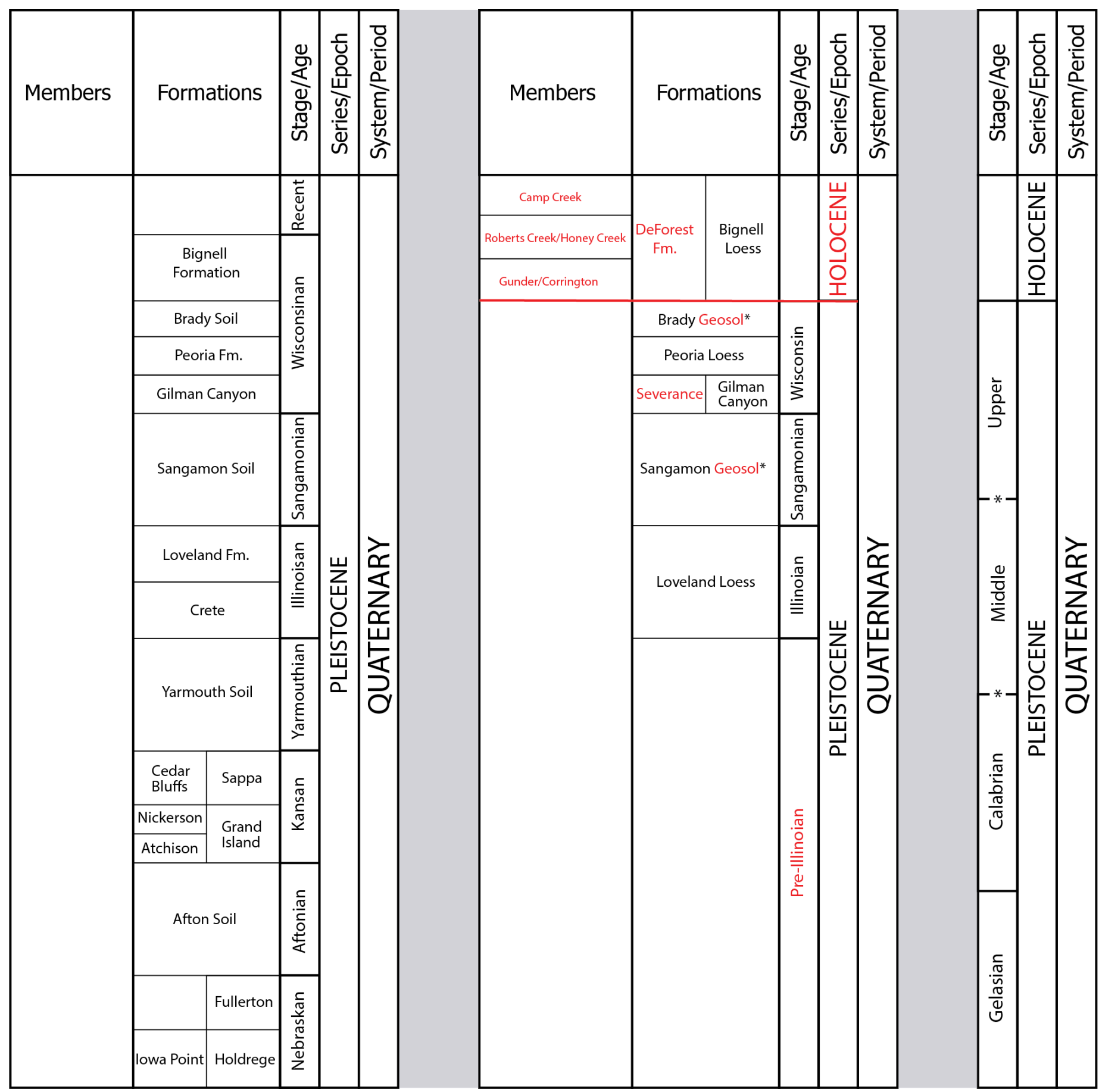

Figure 1. Quaternary nomenclature changes to Zeller (1968) that are now formally adopted by the Kansas Geological Survey. Left column: Zeller (1968), modified according to Bayne and O'Connor (1968). Center column: This paper, changes are highlighted in red; asterisks indicate pedostratigraphic units. Right column: ICS nomenclature, includes superstage boundaries based on formally defined GSSPs; boundaries with asterisks have not been formally ratified by the IUGS ICS. 
Science Reviews documented the then-current state of knowledge regarding Quaternary glaciations and stratigraphy in North America (Richmond and Fullerton, 1986). In that volume, Hallberg presented the Quaternary Stratigraphy of the Central Plains region, including Kansas (Hallberg, 1986). Based on the recognized complexity of the stratigraphy, widespread miscorrelations, and the assignment of erroneous ages to various stratigraphic units, Hallberg recommended that the stage/age names Kansan, Aftonian, and Nebraskan be abandoned and replaced with the broader term "preIllinoian." The North American geologic community has adopted this change, which is recognized by the IUGS ICS SQS (see North American Stages column in Cohen and Gibbard, 2011). Therefore, and in accordance with the Stratigraphic Code of the North American Commission on Stratigraphic Nomenclature (NACSN, 2005; Article 20-Abandonment), this recommendation is formally adopted by the KGS (fig. 1, table 2).

Although Hallberg (1986) did not suggest that the stage/age name Yarmouthian be abandoned, Yarmouth soils in Kansas were formerly identified 1) by the presence of the Pearlette ash (e.g., Frye et al., 1948; Frye and Leonard, 1952) and 2) based on the assumption that the uppermost till in the glacial sequence, in which the Yarmouth soil developed, represented the Kansan Stage (e.g., Frye and Leonard, 1952; Bayne and O'Connor, 1968). Given that 1) the basis for these correlations has been shown to be erroneous (see Hallberg, 1986), 2) no recent studies have identified Yarmouth soils in Kansas, and 3) the Yarmouthian Stage is not recognized by the IUGS ICS SQS (see North American Stages column in Cohen and Gibbard, 2011), the KGS abandons the term Yarmouthian Stage/Age to be replaced with the broader term pre-Illinoian Stage/Age (following NACSN, 2005; Article 20-Abandonment).

\section{Lithostratigraphy}

Quaternary deposits in Kansas consist primarily of unconsolidated eolian, alluvial, and glacial sediments. Bayne and O'Connor (1968) recognized four loess units: the Bignell, Peoria, Gilman Canyon, and Loveland Formations (table 1). These deposits continue to be identified across the state (e.g., Feng, 1997; Johnson and Willey, 2000; Miao et al., 2005; Karlstrom et al., 2008; Layzell et al., 2016). Note that the Stratigraphic Code (NACSN, 2005; Article 7-Name) allows for the names of formal geologic units to include either the appropriate rank (e.g., formation) or descriptive term (e.g., loess). The KGS therefore uses the descriptive term "loess" for the Bignell, Peoria, and Loveland Loesses but maintains the term Gilman Canyon Formation, in accordance with the prevailing usage by the geologic community (fig. 1, table 2).

Bayne and O'Connor (1968) recognized several alluvial lithostratigraphic units in central and western Kansas: Crete, Sappa, Grand Island, Fullerton, and Holdrege Formations (table 1). These formations originally were defined in Nebraska (e.g., Lugn and Condra, 1932; Lugn, 1934; Condra et al., 1947; Reed and Dreeszen, 1965). Since the recommended abandonment of the pre-Illinoian stratigraphic framework, however, these formation names have not been employed in subsequent research and are no longer formally recognized by the Nebraska Geological Survey (see Korus and Joeckel, 2011). Therefore, based on disuse and the lack of useful purpose for these units (NACSN, 2005; Article 20Abandonment), these formation names are no longer considered valid lithostratigraphic units in Kansas and are abandoned (fig. 1, table 2).

Mandel and Bettis (2001) proposed a new lithostratigraphic unit, the Severance Formation, for thick packages of late Pleistocene deposits (alluvium and colluvium) in river valleys of eastern Kansas and Nebraska. The type locality for the Severance Formation is in the Wolf River valley immediately west of the community of Severance in Doniphan County, Kansas. The Severance Formation has subsequently been identified in several river valleys in eastern Kansas and Nebraska (e.g., Mandel, 2006; Baker et al., 2009; Gottsfield, 2009; McLean, 2010; Presley et al., 2010; Beeton and Mandel, 2011; Korus et al., 2013; Mandel et al., 2016). Objections can be raised with regard to using stratigraphic nomenclature for alluvium because of its laterally discontinuous nature. However, distinct alluvial units can be recognized by internally consistent, objectively mappable lithic characteristics and stratigraphic position (following NACSN, 2005; Article 22-Nature of lithostratigraphic units; Article 24-Ranks of lithostratigraphic units-formation). In accordance with the Stratigraphic Code (NACSN, 2005; Article 3-Requirements for formally named geologic units), the KGS accepts the use of Severance Formation as a valid lithostratigraphic unit in eastern Kansas (fig. 1, table 2).

Recent investigations of fine-grained Holocene alluvium in eastern Kansas have adopted the stratigraphic nomenclature for these deposits developed in Iowa. The DeForest Formation is a formal lithostratigraphic unit, delimited on the basis of lithic characteristics and stratigraphic position, that was originally es-

Table 2. Current classification of Quaternary deposits in Kansas (revisions to nomenclature highlighted in red).

\begin{tabular}{|c|c|c|c|c|}
\hline \multirow{2}{*}{ Epoch } & \multirow{2}{*}{ Stage } & \multicolumn{3}{|c|}{ Lithostratigraphic units } \\
\cline { 3 - 5 } & & Loess & Alluvium & Till \\
\hline Holocene & & Bignell Loess & DeForest Fm. & \\
\hline \multirow{3}{*}{ Pleistocene } & \multirow{3}{*}{ Wisconsin } & Brady Geosol & soil & \\
\cline { 3 - 5 } & & Peoria Loess & fluvial deposits & \\
\cline { 3 - 5 } & Gilman Canyon Fm. & Severance Fm. & \\
\cline { 2 - 5 } & Sangamonian & Sangamon Geosol & soil & \\
\cline { 2 - 5 } & Illinoian & Loveland Loess & fluvial deposits & till \\
\cline { 2 - 5 } & pre-Illinoian & loess & fluvial deposits & \\
\hline
\end{tabular}


tablished from a sequence of alluvial fills in small valleys of the Loess Hills in western Iowa (Daniels et al., 1963). Subsequent studies in the Midwest have led to the expansion and revision of the formation (e.g., Bettis, 1990, 1995; Dillon and Mandel, 2006). The DeForest Formation consists of eight formal members, five of which - the Camp Creek, Roberts Creek, Honey Creek, Gunder, and Corrington members - have been identified in Kansas (e.g., Mandel et al., 1991; Mandel and Bettis, 2001; Mandel, 2006; Beeton and Mandel, 2011; Layzell and Mandel, 2014). The KGS recognizes the DeForest Formation as a valid lithostratigraphic unit in eastern Kansas (fig. 1, table 2) because it has 1) yielded consistent stratigraphic relationships across a broad region, including Kansas, 2) been formally adopted by neighboring state geological surveys (i.e., Iowa and Nebraska), and 3) advanced our understanding of fluvial processes and fluvial response to environmental forcing (NACSN, 2005; Article 5-Intent and utility).

Bayne and O'Connor (1968) recognized three distinct till units (Iowa Point, Nickerson, and Cedar Bluffs Tills) and two glaciofluvial deposits (Atchison and David City Formations) in northeastern Kansas (table 1). Many uncertainties, however, still exist with respect to the number, age, and correlations of glacial units in Kansas. For example, questions remain as to how many distinct till deposits are present, with at least two and as many as five described (e.g., Frye and Leonard, 1952; Dort, 1966, 1985; Aber, 1991). Based on the confusion in the stratigraphic nomenclature (see Aber, 1991, and Rovey and Bettis, 2014, for helpful reviews), the disuse of terminology, and the lack of useful purpose for these units (NACSN, 2005; Article 20-Abandonment), the formation names for till units and glaciofluvial deposits in Kansas are abandoned (fig. 1, table 2).

Aber (1991) proposed replacing the formation names for glacial deposits in Kansas with a new lithostratigraphic unit (the Independence Formation), which consists of all diamicton and interbedded stratified glaciofluvial sediments in northeastern Kansas. Age control was provided for the Independence Formation based on the presence of the Lava Creek B ash $(0.62 \mathrm{Ma})$ and the Wathena local fauna (ca. 1.0 Ma). Also, Aber (1991) reported that no sediments with reversed magnetic polarity have been found in northeastern Kansas, thereby further restricting the age of the Independence Formation to either the early Brunhes Chron (0.7-0.6 $\mathrm{Ma})$ or less likely to the Jaramillo subchron (1.0-0.9 Ma). Based on the reported ages and paleomagnetism as well as lithologic similarities, Aber proposed tentative correlations between the Independence Formation and the McCredie Formation of north-central Missouri and the A2 and A3 tills of Boellstorff (1978b).

Recent research, however, brings into question the chronology and correlations of the Independence Formation. Roy et al. (2004) conducted paleomagnetic measurements and collected till compositional data from glacial sequences in Iowa, Nebraska, Missouri, and Kansas. The sites investigated in Kansas included the holostratotype (West Atchison) and parastratotype (Wathena) sections proposed by Aber for the Independence Formation. All tills investigated in Kansas were determined to have reversed magnetic polarity, in contradiction to Aber (1991), with the sole exception of the upper till at the Wathena parastratotype section. Roy et al. (2004) proposed a stratigraphic framework consisting of three till groups: N, R1, and R2 tills. The upper and lower tills from the West Atchison section (site 20 of Roy et al., 2004) were both placed into the R2 group, consisting of till units with reversed magnetic polarity that were likely deposited during the early part of the Matuyama Chron (between ca. 2.5 and 2.0 Ma). The lower till from the Wathena section (site 21) as well as a till previously investigated from the Vitt borrow pit near Seneca, Kansas, (Mandel and Bettis, 2001) (site 18) were placed into the R1 group, consisting of till units with reversed polarity that were likely deposited during the late part of the Matuyama Chron (between ca. 1.3 and $0.8 \mathrm{Ma}$ ). Only the upper till at the Wathena section (site 21) was placed into the $\mathrm{N}$ group, consisting of till units with normal magnetic polarity that were likely deposited during the early Brunhes Chron between ca. 0.8 and $0.6 \mathrm{Ma}$. As the geologic age and correlations are a requirement for formally naming geologic units in the Stratigraphic Code (NACSN, 2005; Article 3-Requirements for formally named geologic units), the KGS does not accept the Independence Formation as a valid lithostratigraphic unit in Kansas.

\section{Pedostratigraphy}

Bayne and O'Connor (1968) recognized four Quaternary pedostratigraphic units: the Afton Soil, Yarmouth Soil, Sangamon Soil, and Brady Soil (table 1). Under the classic four-fold glacial stratigraphic framework, interglacial stages were recognized based on the presence of these soils. Given the accepted abandonment of the pre-Illinoian chronostratigraphic nomenclature and the lack of recent recognition of Afton soils in Kansas, the KGS abandons the term "Afton Soil" (following NACSN, 2005; Article 20Abandonment). Also, although investigations have recently been performed on the Yarmouth Soil in Illinois (e.g., Grimley et al., 2003), the presence of this soil in Kansas is questionable and no recent studies have been undertaken on potential Yarmouth soils in Kansas. Therefore, in accordance with the Stratigraphic Code (NACSN, 2005; Article 20-Abandonment), the KGS does not formally recognize the Yarmouth Soil as a pedostratigraphic unit at this time and the use of the term is abandoned.

The KGS maintains the nomenclature of the Sangamon Soil and Brady Soil, now officially termed the Sangamon Geosol and Brady Geosol, following the Stratigraphic Code (NACSN, 2005; Article 57-Pedostratigraphic nomenclature), as these pedostratigraphic units continue to be identified in Kansas (e.g., Johnson and Willey, 2000; Karlstrom et al., 2008; Layzell et al., 2016) (fig. 1 , table 2). It should be noted that a pedostratigraphic unit can be recognized only by its relation to overlying and underlying stratigraphic units (NACSN, 2005; Article 55c-Pedostratigraphic units - boundaries and stratigraphic position) and therefore the Brady Geosol is recognized only where it is buried by the Bignell Loess.

Research at the type section for the Gilman Canyon Formation in Nebraska recognized the presence of two or more episodes of cumulic soil development (Reed and Dreeszen, 1965; Johnson et al., 2007). Based on its regional expression, Johnson et al. (2007) refer to this soil as an informal pedostratigraphic unit (i.e., the Gilman Canyon geosol) that is coeval with the formally recognized Farmdale Geosol in Illinois (e.g., Folmer, 1983). Although soils developed in the Gilman Canyon Formation have been identified in Kansas (e.g., Feng, 1997; Karlstrom et al., 2008; Bowen and Johnson, 2012; Layzell et al., 2016), to date no attempt has been made to establish the Gilman Canyon geosol as a formal pedostratigraphic unit separate from the Farmdale Geosol (NACSN, 
2005; Article 57c - Pedostratigraphic units - procedures for establishing formal pedostratigraphic units). At this time, the KGS does not recognize the Farmdale Geosol as a formal pedostratigraphic unit because previous studies have not used this nomenclature in Kansas.

\section{Use of informal stratigraphic nomenclature for Quaternary deposits}

The literature contains and researchers in Kansas continue to use many informal formation names for different Pleistocene deposits. Although not mentioned in Zeller (1968), these include, for example, the Meade, McPherson, Sanborn, Kingsdown, Crooked Creek, and Belleville Formations. Frye (1945) argued that local names, representing slightly dissimilar and disconnected deposits, may result in greater clarity and usefulness in the Quaternary classification. Since his 1945 publication, however, many of these informal units have been inconsistently defined by different researchers in different areas. Also, most of the units that defined the boundaries of the formations have subsequently been abandoned. Continued use of these names in the literature, particularly in a formal sense, creates confusion and exacerbates problems with stratigraphic correlation. Therefore, the KGS recommends that the use of these local names be abandoned.

\section{Summary of formally adopted Quaternary stratigraphic nomenclature changes}

1. Following the IUGS ICS SQS, the KGS now recognizes two series/epochs for the Quaternary: the Holocene and Pleistocene. IUGS ICS "super-stages" subdivisions are not adopted because only two have been formally ratified and they have not been established in the Kansas stratigraphic succession.

2. The Pleistocene stage/age names Kansan, Aftonian, Nebraskan, and Yarmouthian are abandoned and replaced with the broader term "pre-Illinoian" based on stratigraphic complexity, widespread miscorrelations, and the assignment of erroneous ages to different stratigraphic units.

3. Formation status for the Bignell, Peoria, and Loveland Loesses and the Gilman Canyon Formation are maintained as these deposits continue to be identified across Kansas and reported in the geologic literature.

4. Formation names Crete, Sappa, Grand Island, Fullerton, and Holdrege for alluvial lithostratigraphic units are abandoned based on disuse and lack of useful purpose.

5. The Severance Formation, proposed by Mandel and Bettis (2001), is accepted as a new lithostratigraphic unit for thick packages of late Pleistocene alluvium and colluvium in Kansas.

6. The DeForest Formation, originally established as a formal lithostratigraphic unit in Iowa, is recognized as a valid lithostratigraphic unit in Kansas. Five members of the DeForest Formation - the Camp Creek, Roberts Creek, Honey Creek, Gunder, and Corrington members-have been identified in the state.

7. Formation names Iowa Point, Nickerson, and Cedar Bluffs for glacial till deposits and Atchison and David City for glaciofluvial deposits are abandoned. The proposal for a new lithostratigraphic unit (the Independence Formation), consisting of all diamicton and interbedded stratified glaciofluvial sediments in northeastern Kansas (Aber, 1991), is not ac- cepted based on recent research that brings into question the chronology and correlations of the Independence Formation (Roy et al., 2004).

8. The names Afton and Yarmouth Soil are abandoned as formal pedostratigraphic units. The KGS maintains the nomenclature of the Sangamon Soil and Brady Soil, now officially termed the Sangamon Geosol and Brady Geosol, as these pedostratigraphic units continue to be identified in Kansas.

\section{KGS Stratigraphic Nomenclature Committee}

This paper was completed by current members of the Kansas Geological Survey's Stratigraphic Nomenclature Committee, which was re-established in July 2005 to address stratigraphic issues and establish formally accepted stratigraphic nomenclature for Kansas. The Stratigraphic Nomenclature Committee is the official arbiter of stratigraphic nomenclature and issues in Kansas, subject to review by the State Geologist. More information about the Committee and Kansas stratigraphic nomenclature is available at http:// www.kgs.ku.edu/General/Strat/index.html.

The Kansas Geological Survey recognizes Zeller (1968) as the current accepted guide and chart for Kansas. Nomenclature changes will follow the North American Stratigraphic Code (NACSN, 2005), and changes will conform to international stratigraphic nomenclature standards as they apply to Kansas.

\section{Acknowledgments}

This manuscript was reviewed by Jeremy Dillon and Jack Oviatt; the authors appreciate their careful and constructive reviews that improved the clarity of the manuscript. Chuck Rovey and Art Bettis also provided helpful direction and insight. The authors also thank Julie Tollefson for editorial and publication assistance.

\section{References}

Aber, J. S., 1991, The glaciation of northeastern Kansas: Boreas, v. 20, no. 4, p. 297-314.

Baker, R. G., Bettis, E. A., Mandel, R. D., Dorale, J. A., and Fredlund, G. G., 2009, Mid-Wisconsinan environments on the eastern Great Plains: Quaternary Science Reviews, v. 28, no. 9, p. 873-889.

Bayne, C. K., and O'Conner, H. G., 1968, Quaternary system; in, The stratigraphic succession in Kansas, D. E. Zeller, ed.: Kansas Geological Survey, Bulletin 189, p. 59-67.

Beeton, J. M., and Mandel, R. D., 2011, Soils and late-Quaternary landscape evolution in the Cottonwood River basin, east-central Kansas: Implications for archaeological research: Geoarchaeology, v. 26, no. 5, p. 693-723.

Bettis, E. A., III, 1990, Holocene alluvial stratigraphy and selected aspects of the Quaternary history of western Iowa: Midwest Friends of the Pleistocene 37th Field Conference Guidebook, Iowa Department of Natural Resources, Geological Survey Bureau, Iowa City.

Bettis, E. A., III, 1995, The Holocene stratigraphic record of entrenched stream systems in thick loess regions of the Mississippi River basin: Ph.D. thesis, University of Iowa, Iowa City.

Boellstorff, J. D., 1976, The succession of late Cenozoic volcanic ashes in the Great Plains: A progress report: Kansas Geological Survey, Guidebook Series, v. 1, p. 37-71.

Boellstorff, J., 1978a, A need for redefinition of North American Pleistocene stages: Gulf Coast Association of Geological Societies Transactions, v. 28, p. 65-74. 
Boellstorff, J., 1978b, Chronology of some late Cenozoic deposits from the central United States and the ice ages: Transactions of the Nebraska Academy of Sciences, v. 6, p. 35-49.

Boellstorff, J., 1978c, North American Pleistocene stages reconsidered in light of probable Pliocene-Pleistocene continental glaciation: Science, v. 202 , no. 4,365 , p. 305-307.

Bowen, M. W., and Johnson, W. C., 2012, Late Quaternary environmental reconstructions of playa-lunette system evolution on the central High Plains of Kansas, United States: Geological Society of America Bulletin, v. 124, p.146-161.

Cohen, K. M., Finney, S. C., Gibbard, P. L., and Fan, J.-X., 2013, The ICS international chronostratigraphic chart: Episodes, v. 36, p. 199-204.

Cohen, K. M., and Gibbard, P. L., 2011, Global chronostratigraphical correlation table for the last 2.7 million years: Subcommission on Quaternary Stratigraphy (International Commission on Stratigraphy), Cambridge, England. http://www.stratigraphy.org/index.php/ics-charttimescale (accessed July 7, 2017).

Condra, G. E., Reed, E. C., and Gordon, E. D., 1947, Correlation of the Pleistocene deposits of Nebraska: Nebraska Geological Survey Bulletin, v. 15, 71 p.

Daniels, R. B., Rubin, M., and Simpson, G. H., 1963, Alluvial chronology of the Thompson Creek watershed, Harrison County, Iowa: American Journal of Science, v. 261, p. 473-484.

Dillon, J. S., and Mandel, R. D., 2006, The Honey Creek Member: A new Holocene alluvial stratigraphic unit in the Midwest: Iowa Academy of Science, v. 113, p. 57-68.

Dort, W., 1966, Nebraskan and Kansan stades: Complexity and importance: Science, v. 154, no. 3,750, p. 771-772.

Dort, W., Jr., 1985, Field evidence for more than two early Pleistocene glaciations of the central plains: TER-QUA symposium series, v. 1, p. 41-51.

Feng, Z.-D., 1997, Geochemical characteristics of a loess-soil sequence in central Kansas: Soil Science Society of America, v. 61, p. 534-541.

Follmer, L. R., 1983, Sangamon and Wisconsinan pedogenesis in the Midwestern United States; in, Late Quaternary Environments of the United States, the Late Pleistocene vol. 1., H. E. Wright and S. C. Porter, eds.: University of Minnesota Press, Minneapolis, p. 138-144.

Frye, J. C., 1945, Problems of Pleistocene stratigraphy in central and western Kansas: Journal of Geology, v. 53, p. 73-93.

Frye, J. C., and Leonard, A. B., 1952, Pleistocene geology of Kansas: Kansas Geological Survey, Bulletin 99, 230 p.

Frye, J. C., Swineford, A., and Leonard, A. B., 1948, Correlation of Pleistocene deposits of the central Great Plains with the glacial section: The Journal of Geology, v. 56, no. 6, p. 501-525.

Gottsfield, A. S., 2009, Late-Quaternary stratigraphy and geoarchaeology of the upper Neosho River basin, east-central Kansas: MS Thesis, University of Kansas, Lawrence, Kansas, 166 p.

Grimley, D. A., Follmer, L. R., Hughes, R. E., and Solheid, P. A., 2003, Modern, Sangamon and Yarmouth soil development in loess of unglaciated southwestern Illinois: Quaternary Science Reviews, v. 22, p. 225-244.

Hallberg, G. R., 1986, Pre-Wisconsin glacial stratigraphy of the central plains region in Iowa, Nebraska, Kansas, and Missouri: Quaternary Science Reviews, v. 5, p. 11-15.

Izett, G. A., 1981, Volcanic ash beds: Recorders of upper Cenozoic silicic pyroclastic volcanism in the western United States: Journal of Geophysical Research: Solid Earth, v. 86, no. B11, p. 10,200-10,222.
Izett, G. A., and Wilcox, R. E., 1982, Map showing localities and inferred distribution of the Huckleberry Ridge, Mesa Falls, and Lava Creek ash beds (Pearlette family ash beds) of Pliocene and Pleistocene age in the western United States and Canada: U.S. Geological Survey, Miscellaneous Investigations Series Map 1-1325, scale 1:4,000,000.

Johnson, W. C., and Willey, K. L., 2000, Isotopic and rock magnetic expression of environmental change at the Pleistocene-Holocene transition in the central Great Plains: Quaternary International, v. 67, p. 89-106.

Johnson, W. C., Willey, K. L., Mason, J. A., and May, D. W., 2007, Stratigraphy and environmental reconstruction at the middle Wisconsinan Gilman Canyon formation type locality, Buzzard's Roost, southwestern Nebraska, USA: Quaternary Research, v. 67, p. 474-486.

Karlstrom, E. T., Oviatt, C. G., and Ransom, M. D., 2008, Paleoenvironmental interpretation of multiple soil-loess sequence at Milford Reservoir, northeastern Kansas: Catena, v. 72, no. 1, p. 113-128.

Korus, J. T., and Joeckel, R. M., 2011, Generalized geologic and hydrostratigraphic framework of Nebraska: Conservation and Survey Division, School of Natural Resources, Institute of Agriculture and Natural Resources, University of Nebraska-Lincoln, Geologic Maps and Charts 38, 1 p. http://snr.unl.edu/csd/download/GMC-38.pdf (accessed 7/6/2017).

Korus, J. T., Joeckel, R. M., and Divine, D., 2013, Three-dimensional hydrostratigraphy of the Firth, Nebraska area: Results from helicopter electromagnetic (HEM) mapping in the Eastern Nebraska Water Resources Assessment (ENWRA): Conservation and Survey Division, School of Natural Resources, Institute of Agriculture and Natural Resources, University of Nebraska-Lincoln, Conservation Bulletin 3 (New Series), $100 \mathrm{p}$.

Layzell, A. L., and Mandel, R. D., 2014, An assessment of the erodibility of Holocene lithounits comprising streambanks in northeastern Kansas, USA: Geomorphology, v. 213, p. 116-127.

Layzell, A. L., Mandel, R. D., Rittenour, T. M., Smith, J. J., Harlow, R. H., and Ludvigson, G. A., 2016, Stratigraphy, morphology, and geochemistry of late Quaternary buried soils on the High Plains of southwestern Kansas, USA: Catena, v. 144, p. 45-55.

Lugn, A.L., 1934, Outline of Pleistocene geology of Nebraska: Nebraska State Museum Bulletin, v. 41, p. 319-356.

Lugn, A. L., and Condra, G., 1932, Pleistocene formations of Southern Nebraska (abstract): Geological Society of America Bulletin, v. 43, p. 190.

Mandel, R. D., 2006, Geomorphology, Quaternary stratigraphy, and geoarchaeology of Fox Creek valley, Tallgrass Prairie National Preserve, northeastern Kansas: Kansas Geological Survey, Open-File Report 2006-29, 52 p.

Mandel, R. D., and Bettis, E. A., III, 2001, Late Quaternary landscape evolution in the South Fork of the Big Nemaha River Valley, Southeastern Nebraska and Northeastern Kansas: Guidebook No. 11, Conservation and Survey Division, University of Nebraska, Lincoln.

Mandel, R. D., Bettis, E. A., III, and Hanson, P. R., 2016, Characteristics and geochronology of the Severance Formation: A new mid- through late Wisconsinan lithostratigraphic unit in the eastern plains of North America: Geological Society of America Abstracts with Programs, v. 48, no. 7, doi: 10.1130/abs/2016AM-286301.

Mandel, R. D., Reynolds, J. D., Williams, B. G., and Wulfkuhle, V. A., 1991, Upper Delaware river and tributaries watershed: Results of 
geomorphological and archeological studies in Atchison, Brown, Jackson, and Nemaha Counties, Kansas: Contract Archeology Publication No. 9, Kansas State Historical Society, 130 p.

McLean, J. A., 2010, A reassessment of the significance of the Coffey Site (14PO1), Tuttle Creek Lake, Pottawatomie County, Kansas: MS thesis, University of Kansas, Lawrence, Kansas, 95 p.

Miao, X., Mason, J., Goblet, R. J., and Hanson, P. R., 2005, Loess record of dry climate and aeolian activity in the early- to mid-Holocene, central Great Plains, North America: The Holocene, v. 15, no. 3, p. 339-346.

NACSN (North American Commission on Stratigraphic Nomenclature), 2005, North American Stratigraphic code: American Association of Petroleum Geologists Bulletin, v. 89, p. 1,547-1,591.

Naeser, C. W., Izett, G. A., and Wilcox, R. E., 1973, Zircon fission-track ages of Pearlette family ash beds in Meade County, Kansas: Geology, v. 1, no. 4, p. 187-189.

Presley, D. R., Hartley, P. E., and Ransom, M. D., 2010, Mineralogy and morphological properties of buried polygenetic paleosols formed in late quaternary sediments on upland landscapes of the central plains, USA: Geoderma, v. 154, no. 3, p. 508-517.

Reed, E. C., and Dreeszen, V. H., 1965, Revision of the classification of the Pleistocene deposits of Nebraska: University of Nebraska, Conservation and Survey Division, Bulletin 23, 65 p.

Riccardi, A. C., 2009, IUGS ratified ICS recommendation on redefinition of Pleistocene and formal definition of base of Quaternary: International Union of Geological Sciences. http://www. stratigraphy. org/upload/ IUGS\% 20Ratification_Q\% 20\&\% 20Pleistocene.pdf.
Richmond, G. M., and Fullerton, D. S., 1986, Summation of Quaternary glaciations in the United States of America: Quaternary Science Reviews, v. 5, p. 183-196.

Rovey, C. W., and Bettis, E. A., III, 2014, Pleistocene geology and classic type sections along the Missouri River valley in western Iowa; in, Geologic Field Trips along the Boundary between the Central Lowlands and Great Plains, J. T. Korus, ed.: Geological Society of America Field Guide 36, p. 23-38.

Roy, M., Clark, P. U., Barendregt, R. W., Glasmann, J. R., and Enkin, R. J., 2004, Glacial stratigraphy and paleomagnetism of late Cenozoic deposits of the north-central United States: Geological Society of America Bulletin, v. 116, no. 1-2, p. 30-41.

Walker, M., Johnsen, S., Rasmussen, S. O., Popp, T., Steffensen, J.-P., Gibbard, P., Hoek, W., Lowe, J., Andrews, J., Björck, S., Cwynar, L. C., Hughen, K., Kershaw, P., Kromer, B., Litt, T., Lowe, D. J., Nakagawa, T., Newnham, R., and Schwander, J., 2009, Formal definition and dating of the GSSP (Global Stratotype Section and Point) for the base of the Holocene using the Greenland NGRIP ice core, and selected auxiliary records: Journal of Quaternary Science, v. 24, p. 3-17.

Ward, P. A., Carter, B. J., and Weaver, B., 1993, Volcanic ashes: Time markers in soil parent materials of the southern plains: Soil Science Society of America Journal, v. 57, no. 2, p. 453-460.

Zeller, D. E., 1968, The stratigraphic succession in Kansas: Kansas Geological Survey, Bulletin 189, 81 p., 1 plate. 


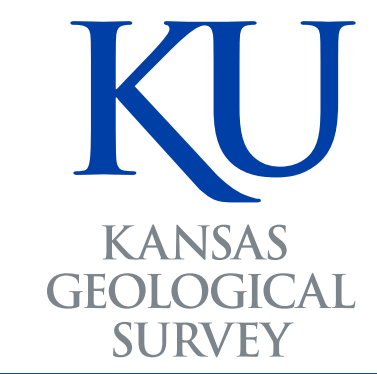

The University of Kansas

Current Research in Earth Sciences is a peer-reviewed publication of the Kansas Geological Survey, a division of the University of Kansas. Each annual issue of this bulletin contains short articles about earth-science research in the midcontinent (North Dakota, South Dakota, Nebraska, Kansas, Oklahoma, Minnesota, Iowa, Missouri).

As part of the KGS Bulletin series, Current Research in Earth Sciences has national and international circulation. Manuscripts are expected to be of high quality. Articles submitted to this bulletin will be published online following peer review, revision, acceptance, and editing. KGS Bulletins are archived electronically.

Submission information: http://www.kgs.ku.edu/Current/submit.html

Kansas Geological Survey

1930 Constant Avenue

The University of Kansas

Lawrence, KS 66047-3724

785.864 .3965

http://www.kgs.ku.edu/

November 2017 